\title{
Effect of Low versus High Intravenous Amino Acid Intake on Very Low Birth Weight Infants in the Early Neonatal Period
}

\author{
PATTI J. THUREEN, DIANE MELARA, PAUL V. FENNESSEY, AND WILLIAM W. HAY, JR. \\ Section of Neonatology, Department of Pediatrics, University of Colorado Health Sciences Center, \\ Denver, Colorado, 80262, U.S.A.
}

\begin{abstract}
Greater protein intakes are required than have been commonly used to achieve fetal in utero protein accretion rates in preterm neonates. To study the efficacy and safety of more aggressive amino acid intake, we performed a prospective randomized study in 28 infants [mean wt, $946 \pm 40 \mathrm{~g}$ (SEM)] of 1 (low amino acid intake, LAA) versus $3 \mathrm{~g} \cdot \mathrm{kg}^{-1} \cdot \mathrm{d}^{-1}$ (high amino acid intake, HAA) at $52.0 \pm 3.0 \mathrm{~h}$ of life. After a minimum of $12 \mathrm{~h}$ of parenteral nutrition, efficacy was determined by protein balance and was significantly lower in the LAA versus HAA groups by both nitrogen balance $(-0.26 \pm 0.11$ versus $1.16 \pm$ $\left.0.15 \mathrm{~g} \cdot \mathrm{kg}^{-1} \cdot \mathrm{d}^{-1}, p<0.00005\right)$ and leucine stable isotope $(0.184$ \pm 0.17 versus $\left.1.63 \pm 0.20 \mathrm{~g} \cdot \mathrm{kg}^{-1} \cdot \mathrm{d}^{-1}, p<0.0005\right)$ methods. Leucine flux and oxidation and nonoxidative leucine disposal rates were all significantly higher in the HAA versus LAA groups ( $249 \pm 13$ versus $164 \pm 8,69 \pm 5$ versus $32 \pm 3$, and 180 \pm 10 versus $132 \pm 8 \mu \mathrm{mol} \cdot \mathrm{kg}^{-1} \cdot \mathrm{h}^{-1}$, respectively, $\left.p<0.005\right)$, but leucine appearance from protein breakdown was not (140 \pm 15 in HAA versus $128 \pm 8 \mu \mathrm{mol} \cdot \mathrm{kg}^{-1} \cdot \mathrm{h}^{-1}$ ). In terms of possible toxicity with HAA, there were no significant differences between groups in the amount of sodium bicarbonate administered, degree
\end{abstract}

\section{ABSTRACT}

of acidosis as determined by base deficit, or blood urea nitrogen concentration. Parenteral HAA versus LAA intake resulted in increased protein accretion, primarily by increasing protein synthesis versus suppressing protein breakdown, and appeared to be well tolerated by very preterm infants in the first days of life.

(Pediatr Res 53: 24-32, 2003)

Abbreviations
PN, parenteral nutrition
LAA, low amino acid intake
HAA, high amino acid intake
Int $_{\text {leuc, leucine intake rate }}$
$\mathbf{Q}_{\text {leuc, leucine flux rate }}$
Ox $_{\text {leuc, }}$, leucine oxidation rate
NOD $_{\text {leuc }}$, nonoxidative leucine disposal intake rate
RP $_{\text {leuc }}$, rate of leucine appearance from protein breakdown
ELBW, extremely low birth weight
BUN, blood urea nitrogen
GCMS, gas chromatography-mass spectroscopy

The current standard for postnatal nutrition in all preterm infants is one that duplicates normal in utero fetal growth rates (1). Owing to advances in perinatal care, more very preterm infants are surviving. These infants have unique nutritional metabolic requirements for growth, predicted by low energy stores, high protein flux rate, and a high metabolic rate as a result of a relatively larger mass of metabolically active organs. Nevertheless, it is common practice in many neonatal intensive care units to limit nutrient administration, particularly amino acids, to ELBW or sick neonates in the early neonatal period

Received February 27, 2002; accepted July 16, 2002.

Correspondence: Patti J. Thureen, M.D., Section of Neonatology, B-195, University of Colorado Health Sciences Center, 4200 East 9th Avenue, Denver, CO 80262, U.S.A.; e-mail: patti.thureen@uchsc.edu

Supported by National Institutes of Health Grants R03 HD39842 and M01 RR00069, General Clinical Research Center Program, National Centers for Research Resources, and The Children's Hospital Research Institute.

DOI: 10.1203/01.PDR.0000042441.34920.77 because of concerns of substrate intolerance. Several studies suggest that this delay in nutrition results in postnatal malnutrition that produces measurable growth failure at hospital discharge (2-4).

Although strategies to improve growth necessitate delivery of larger amounts of both energy and protein beginning shortly after birth, there are reasons to suggest that focusing on protein delivery may be particularly important. Throughout life, maximal weight-specific protein gain occurs before $32 \mathrm{wk}$ gestation (5). Data from studies in fetal animal models suggest that amino acid metabolic rates may be a much more sensitive indicator than growth rate of adequate nutrition before term (6). Additionally, recent data suggest that long-term developmental outcome in the preterm may be correlated with early protein intake (7). Several studies regarding early introduction of amino acids in preterm infants have demonstrated that infusion of amino acids with glucose in the early neonatal period decreases protein breakdown compared with glucose 
alone, and does not appear to be associated with toxicity $(8-19)$. However, these studies have generally included only modest protein intakes that have resulted in minimally anabolic states. Studies to date have not investigated amino acid intakes sufficient to approximate fetal protein accretion rates.

To test the safety and efficacy of early amino acid intake rates that more closely approach fetal delivery rates, we conducted a prospective, randomized trial in very preterm neonates of early parenteral administration of "low" (1 $\left.\mathrm{g} \cdot \mathrm{kg}^{-1} \cdot \mathrm{d}^{-1}\right)$ versus "high" $\left(3 \mathrm{~g} \cdot \mathrm{kg}^{-1} \cdot \mathrm{d}^{-1}\right)$ amino acid intake.

\section{METHODS}

Subjects. This protocol was approved by the Combined Institutional Review Board for human subject research for The Children's Hospital of Denver and the University Hospital at the University of Colorado Health Sciences Center. Subjects were recruited from the neonatal intensive care units in the first day of life. Informed parental consent was obtained before all studies. All newborns who were mechanically ventilated, $\leq 1300 \mathrm{~g}$ in weight, anticipated to receive exclusive PN for the first $48 \mathrm{~h}$ of life, and medically stable according to their attending physician were considered for inclusion. Exclusion criteria included sepsis and congenital or metabolic abnormalities known to affect energy or nutrient metabolism.

Study Design. As soon as consent was obtained, the infant was randomized to start on PN with either $1.0 \mathrm{~g} \cdot \mathrm{kg}^{-1} \cdot \mathrm{d}^{-1}$ (LAA group) or $3.0 \mathrm{~g} \cdot \mathrm{kg}^{-1} \cdot \mathrm{d}^{-1}$ (HAA group) amino acids (TrophAmine, McGaw, Irvine, CA, U.S.A., with added cysteine hydrochloride, Abbott, Abbott Park, IL, U.S.A.). All infants were prescribed $1 \mathrm{~g} \cdot \mathrm{kg}^{-1} \cdot \mathrm{d}^{-1}$ lipid (Intralipid $20 \%$, Fresenius Kabi Clayton, L.P., Clayton, NC, U.S.A.). Glucose was administered at intakes to maintain serum glucose concentrations $>80-100 \mathrm{mg} / \mathrm{dL}$ but which avoided hyperglycemia (i.e. serum glucose concentrations $>120-150 \mathrm{mg} / \mathrm{dL}$ plus glucosuria). Target energy intakes (glucose plus lipid) were $35-40 \mathrm{kcal} \cdot \mathrm{kg}^{-1} \cdot \mathrm{d}^{-1}$. Minerals, trace elements, and vitamins were provided according to nursery protocol. After a minimum of $12 \mathrm{~h}$ on PN, urine collections for nitrogen balance studies were begun. Shortly thereafter infants were given a primed, constant infusion of leucine and glucose labeled with stable isotopes to determine protein kinetics and protein balance as well as glucose flux rates.

Isotope Infusions, Laboratory Determinations, and Indirect Calorimetry Measurements. Infants were enrolled in isotope studies if parents consented to blood sampling and if endotracheal tube air leak was $<5 \%$ to ensure accurate carbon dioxide production measurements. Infants were administered a priming dose of $\left[1-{ }^{13} \mathrm{C}\right]$ leucine $(1.0 \mathrm{mg} / \mathrm{kg}=7.6 \mu \mathrm{mol} / \mathrm{kg})$ and $[6,6-$ $2 \mathrm{H} 2$ ]glucose $(3.6 \mathrm{mg} / \mathrm{kg})$. The bicarbonate pool was primed with $6.9 \mu \mathrm{mol} / \mathrm{kg}$ of $\mathrm{NaH}^{13} \mathrm{CO}_{2}$. This was followed by continuous infusions of $\left[1-{ }^{13} \mathrm{C}\right]$ leucine $\left(1.0 \mathrm{mg} \cdot \mathrm{kg}^{-1} \cdot \mathrm{h}^{-1}=7.6\right.$ $\left.\mu \mathrm{mol} \cdot \mathrm{kg}^{-1} \cdot \mathrm{h}^{-1}\right)$ and $\left[6,6-\mathrm{D}_{2}\right]$ glucose $\left(2.4 \mathrm{mg} \cdot \mathrm{kg}^{-1} \cdot \mathrm{h}^{-1}=13.3\right.$ $\left.\mu \mathrm{mol} \cdot \mathrm{kg}^{-1} \cdot \mathrm{h}^{-1}\right)$. All isotopes were obtained from Cambridge Isotope Laboratories (Woburn, MA, U.S.A.). These were delivered either through a central venous catheter or an indwelling i.v. catheter in an extremity. Blood samples were drawn from an indwelling arterial catheter or from a central venous line that was not the infusion line. Blood samples $(0.4 \mathrm{~mL})$ were drawn at time 0 and then at approximately 240,270, and 300 min after starting the infusions. Samples were placed in heparinized tubes and centrifuged at $4^{\circ} \mathrm{C}$, and the plasma was stored at $-20^{\circ} \mathrm{C}$ until analysis. These samples were used to measure ${ }^{13} \mathrm{C}$ enrichment of plasma leucine and deuterated enrichment of glucose. Breath samples for ${ }^{13} \mathrm{CO}_{2}$ were taken from the expired gas limb of the ventilator circuit at times corresponding to the above blood samples. Our prior studies in preterm infants have demonstrated that steady-state plasma isotope enrichments are established by 120 $180 \mathrm{~min}$ after initiation of the above constant isotope infusion rate, but that steady-state enrichment of exhaled ${ }^{13} \mathrm{CO}_{2}$ may not be established for $4-5 \mathrm{~h}$.

Urine collections for determination of urinary nitrogen excretion were performed commencing at the time of the isotope study. This urine collection was used to calculate protein balance by the nitrogen balance method. Urine output was determined by hourly withdrawal of urine from specially prepared urine bags scaled for infant size and by weighing tared diapers when urine spillage occurred. Stool contamination was minimal because infants were not enterally fed. For infants whose parents chose not to consent to the stable isotope infusion portion of the study, nitrogen balance studies alone were used to assess protein balance. Blood samples also were obtained for plasma amino acid, creatinine, BUN, glucose, insulin, and triglyceride concentrations at the start of the nitrogen balance study.

Metabolic measurements, specifically carbon dioxide production rates, were determined using indirect calorimetry for a 4- to 6-h period during the isotope infusion. The validation of the indirect calorimeter used in this study (Neoscope) has been reported previously (20), and patients in this study were ventilated with the same ventilators used in the validation testing of the indirect calorimeter [i.e. Sechrist IV-100-B Ventilator (Sechrist Industries, Inc., Anaheim, CA, U.S.A.), Infant Star Neonatal Ventilator (Infrasonics, Inc., San Diego, CA, U.S.A.) and Bear Cub Infant Ventilator (Bear Medical Systems, Inc., Riverside, CA, U.S.A.)]. To ensure accuracy of metabolic measurements and exhaled ${ }^{13} \mathrm{CO}_{2}$ breath samples, indirect calorimetry and breath collection were done only if it was determined that endotracheal tube air leak was $<5 \%$. The percentage air leak was calculated by directly measuring the infant's inspired and expired gas flow. The latter was accomplished by sequentially placing a Fleisch pneumotachometer (Cybermedic, Inc., Boulder, CO, U.S.A.) on the inspiratory and expiratory limbs of the ventilator circuit near the patient wye and measuring the volume of gas flow at both sites. The percent endotracheal tube gas leak was then calculated as:

$$
\begin{array}{r}
\text { inspiratory gas flow }\left(L \cdot \text { min }^{-1}\right) \\
- \text { expiratory gas flow }\left(L \cdot \text { min }^{-1}\right)
\end{array}
$$

On a scheduled basis, the accuracy and reproducibility of the system was validated by combustion of absolute ethyl alcohol in the system.

Severity of illness at the time of study was determined by two different severity-of-illness scores that have been used in 
the neonate [Score for Neonatal Acute Physiology or SNAP (21), and the Neonatal Therapeutic Intervention Scoring System or NTISS (22)].

Analyses. Plasma leucine enrichments were determined following the methodology previously described for leucine (23). After deproteinization with barium hydroxide and zinc sulfate followed by purification on an ion exchange column, acetate derivatives of glucose were prepared for GCMS analysis. All analyses (leucine and glucose) were performed on a HewlettPackard 5890 gas chromatograph (GC) fitted with a 7673T Autosampler and interfaced to a 5970 mass selective detector and a Hewlett-Packard-9000 work station. Multiple ion selection was performed on derivatized samples. The concentration of each isotopically labeled substrate was determined by isotopic dilution technique via GCMS using an internal standard. The actual infusion rate was determined by weighing the infusion syringe and tubing before and after the study, and was confirmed by calculating the regression of multiple time point determinations of infused volume versus time of infusion.

Breath ${ }^{13} \mathrm{CO}_{2}$ enrichments were analyzed by isotope ratio mass spectrometry (Metabolic Solutions, Acton, MA, U.S.A.). The ${ }^{13} \mathrm{C}$ enrichment of blood bicarbonate was measured after separation of the $\mathrm{CO}_{2}$ by cryogenic distillation under vacuum (24). In addition to GCMS glucose concentration determinations, periodic plasma glucose measurements during the study were determined by the glucose oxidase method using a glucose analyzer on $25 \mu \mathrm{L}$ of sample (Yellow Springs Instrument Co., Yellow Springs, OH, U.S.A.). Blood samples for determination of plasma amino acid concentrations were collected in EDTA-coated syringes and centrifuged, and the plasma was stored at $-70^{\circ} \mathrm{C}$ until analysis. Plasma concentrations were measured using a Dionex 300 Model 4500 amino acid analyzer (Dionex Corp., Sunnyvale, CA, U.S.A.) after deproteinization with sulfosalicylic acid.

Calculations. Nitrogen balance was calculated as nitrogen intake minus urinary nitrogen excretion, expressed as grams per kilogram per day. Urinary nitrogen collections ranged from 6 to $24 \mathrm{~h}$. In infants receiving PN, collections of 6-12 h duration accurately reflect 24 -h collections $(25,26)$. Nitrogen intake is calculated from the amount of amino acid intake during the $24 \mathrm{~h}$ before the start of the study (i.e. grams of nitrogen intake $=0.156 \times$ grams of amino acid intake). Both cutaneous and stool nitrogen losses were considered to be negligible in this population of infants who have minimal sweat losses and minimal stool losses when on parenteral intake only.

The model for determining various aspects of leucine metabolism is based on the following mass equation (27):

$$
\mathrm{Q}_{\text {leuc }}=\mathrm{NOD}_{\text {leuc }}+\mathrm{Ox}_{\text {leuc }}=\mathrm{RP}_{\text {leuc }}+\mathrm{Int}_{\text {leuc }}
$$

where $\mathrm{Q}_{\text {leuc }}$ is the leucine flux rate, $\mathrm{NOD}_{\text {leuc }}$ is the rate of nonoxidative leucine disposal or incorporation of leucine into protein (which can be used to estimate protein synthesis), $\mathrm{Ox}_{\text {leuc }}$ is the rate of leucine oxidation, $\mathrm{RP}_{\text {leuc }}$ is the rate of leucine release from protein breakdown or the endogenous leucine appearance rate (which can be used to estimate protein breakdown), and Int leuc $_{\text {in }}$ is the leucine intake (dietary leucine plus the infused leucine tracer). Whole body leucine flux rate $\left(\mathrm{Q}_{\text {leuc }}\right.$, micromoles per kilogram per hour) is calculated from the steady-state dilution of the infused leucine tracer as:

$$
\mathrm{Q}_{\text {leuc }}=\operatorname{Inf}_{\mathrm{r}} \times\left(\mathrm{MPE}_{\mathrm{Inf}} / \mathrm{MPE}_{\mathrm{P}}-1\right)
$$

where $\operatorname{Inf}_{\mathrm{r}}$ is the infusion rate of the labeled leucine (micromoles per kilogram per hour), $\mathrm{MPE}_{\mathrm{Inf}}$ is the leucine enrichment of the infusate, and $\mathrm{MPE}_{\mathrm{P}}$ is the plasma enrichment of the leucine at steady state. From exhaled breath measurements, leucine oxidation $\left(\mathrm{Ox}_{\text {leuc }}\right.$, micromoles per kilogram per hour) is determined as:

$$
\mathrm{Ox}_{\text {leuc }}=\frac{\dot{\mathrm{V}}_{\mathrm{CO}_{2}} \times{ }^{13} \mathrm{CO}_{2} \mathrm{MPE}}{\left[{ }^{13} \mathrm{C}\right] \text { Leuc MPE } \times 0.8}
$$

where $\dot{\mathrm{V}}_{\mathrm{CO}_{2}}$ is the rate of $\mathrm{CO}_{2}$ production (micromoles per kilogram per hour), ${ }^{13} \mathrm{CO}_{2}$ MPE is the ${ }^{13} \mathrm{C}$ enrichment of expired $\mathrm{CO}_{2}$ at steady state, and 0.8 is a constant representing the fractional recovery of ${ }^{13} \mathrm{CO}_{2}$ obtained during ${ }^{13} \mathrm{C}$ bicarbonate infusions in adults and newborns that corrects for the loss of the ${ }^{13} \mathrm{C}$ label $(28,29)$. From the above, $\mathrm{NOD}_{\text {leuc }}$ and $\mathrm{RP}_{\text {leuc }}$ can then be determined using Equation 1 above. Leucine balance $\left(\mathrm{Bal}_{\text {leuc }}\right)$ is calculated as:

$$
\mathrm{Bal}_{\text {leuc }}=\mathrm{NOD}_{\text {leuc }}-\mathrm{RP}_{\text {leuc }}
$$

Because leucine is an essential amino acid, and with the assumption that the average leucine content of protein is 590 $\mu \mathrm{mol} / \mathrm{g}$ protein $(30)$, whole body protein synthesis rate $\left(\mathrm{S}_{\mathrm{pro}}\right)$ and catabolism rate $\left(\mathrm{C}_{\text {pro }}\right)$ can be extrapolated from leucine kinetic data. Whole body protein balance $\left(\mathrm{Bal}_{\text {pro }}\right)$ is then estimated as:

$$
\mathrm{Bal}_{\text {pro }}=\mathrm{S}_{\text {pro }}-\mathrm{C}_{\text {pro }}
$$

For this study protein balance is considered to be positive or anabolic if $>0 \mathrm{~g} \cdot \mathrm{kg}^{-1} \cdot \mathrm{d}^{-1}$, and negative or catabolic if $<0$ $\mathrm{g} \cdot \mathrm{kg}^{-1} \cdot \mathrm{d}^{-1}$.

Glucose flux rate was calculated as for leucine flux rate in Equation 1.

Statistical Methods. The primary outcome variable in this study was protein balance as determined by the stable isotope method. Based on SD data from prior studies conducted in our nurseries and a difference in protein balance of $1.0 \mathrm{~g} \cdot \mathrm{kg}^{-1} \cdot \mathrm{d}^{-1}$ between the LAA and HAA intakes to be deemed clinically significant, it was estimated that 11 infants were required in each study group to demonstrate a reasonable $(90 \%)$ chance of detecting a significant difference $(p<0.05)$ in protein balance between the two groups. Data are presented as mean \pm SEM. Differences between study groups were tested by unpaired, two-tailed $t$ test. Regression analyses were performed to assess the correlation between leucine intake and leucine kinetic data, glucose intake and flux rate, and the impact of amino acid intake on BUN and urinary nitrogen excretion.

\section{RESULTS}

Study group subject demographics are compared in Table 1. Twenty-eight infants were studied in all, 13 neonates in the LAA and 15 neonates in the HAA study groups. The mean age 
Table 1. Subject demographic characteristics and clinical features

\begin{tabular}{lcc}
\hline & Low amino acid intake group & High amino acid intake group \\
\hline Number of infants & 13 & 15 \\
Birth weight $(\mathrm{kg})$ & $0.945 \pm 0.052$ & $0.947 \pm 0.060$ \\
Gestational age at birth (wk) & $27.3 \pm 0.4$ & $27.0 \pm 0.6$ \\
Birth to start of PN (h) & $22.6 \pm 3.5$ & $26.0 \pm 3.0$ \\
Time on PN at start of isotope study (h) & $22.8 \pm 3.4$ & $31.6 \pm 3.4$ \\
Number $>$ 10th centile/ $<$ 10th centile for weight & $12 / 1$ & $14 / 1$ \\
SNAP & $10.3 \pm 1.0$ & $10.4 \pm 1.3$ \\
NTISS & $24.4 \pm 0.8$ & $26.3 \pm 0.8$ \\
\hline
\end{tabular}

Numeric values expressed as mean \pm SEM. There were no significant differences between groups for any of the above parameters.

at starting the study amino acid infusion rates was 22.6 and $26.0 \mathrm{~h}$ in the low versus high intake groups, respectively and the mean age at study was $52.0 \pm 3.0 \mathrm{~h}$ of life. The time of study onset was primarily a result of the time required by parents to decide to give consent for their infant's participation. All infants were mechanically ventilated and on exclusive PN during the study. Patient groups were comparable in gestational age, birth weight, age at study, and severity of illness. One infant in each group was $<10 \%$ for weight at the time of birth. Although a number of infants in both groups were receiving antibiotics, no infants had positive blood culture results. Because all mothers had received antibiotic in the immediate predelivery period, lack of positive culture results was not unanticipated. None of the infants received postnatal corticosteroids. However, maternal betamethasone was administered within $48 \mathrm{~h}$ before delivery in 10 infants in the LAA group and seven infants in the HAA group. In addition, although most mothers had received antibiotics before delivery, mothers of four infants in the LAA group and three in the HAA group were presumed to have chorioamnionitis at the time of delivery. Dietary intakes during the study are shown in Table 2. As anticipated by study design, amino acid intake was significantly greater in the HAA group, but energy intakes were comparable between study groups.

Protein balance was determined by both leucine isotope and nitrogen balance methods. Nitrogen balance studies were performed in all subjects. Figure 1 shows the results in the two amino acid intake groups for the components of the nitrogen balance technique. Eleven subjects in each group completed isotope studies. Figure 2 compares protein balance at LAA and HAA intakes in the 11 subjects who had protein balance determined by the nitrogen balance and isotope methods. There was a strong correlation between amino acid intake and calculated protein balance for both techniques $\left(r^{2}=0.76, p<\right.$ 0.0001 for isotope method and $r^{2}=0.79, p<0.0001$ for nitrogen balance method).
Leucine kinetic data in the two intake groups are shown in Table 3. Actual PN nutrient administration and prescribed PN intakes were not always the same, providing a range of amino acid intakes within the LAA and HAA study groups. There was a strong correlation between leucine intake and both of the measured kinetic values, leucine flux rate and leucine oxidation rate (Fig. 3, Top). The calculated values of nonoxidative leucine disposal rate and leucine balance rate were correlated with leucine intake (Fig. 3, Bottom), but leucine appearance from protein breakdown was not (NS).

Glucose flux rates were similar in the two amino acid intake groups, $35.4 \pm 4.1$ and $34.7 \pm 2.8 \mu \mathrm{mol} \cdot \mathrm{kg}^{-1} \cdot \mathrm{min}^{-1}$ in the LAA and HAA intake groups, respectively. When the data from all subjects were analyzed, there was a strong correlation between glucose intake and glucose flux rate $\left(r^{2}=0.70, p<0.0001\right)$.

Laboratory results are shown in Table 4. Glucose and triglyceride concentrations were similar in the two intake groups. There were no significant differences between groups in the amount of sodium bicarbonate administered during the study $(n$ $=5$ in each group) or degree of acidosis as determined by base deficit (mean base deficit from blood gas measurements during the study were $-3.4 \pm 0.6$ versus $-4.1 \pm 0.7 \mathrm{mEq} / \mathrm{L}$ in the LAA versus HAA intake groups, respectively). BUN concentration was similar between groups. Urea nitrogen is often used as a marker for possible amino acid toxicity. In this study there was no correlation between amino acid intake and BUN $\left(r^{2}=\right.$ 0.08 , NS). A subset of patients ( $n=9$ LAA and $n=13$ HAA infants) had plasma insulin concentrations measured, and they were significantly higher in the HAA study group. Carbon dioxide production rate was $224 \pm 7$ versus $252 \pm 8$ $\mu \mathrm{mol} \cdot \mathrm{kg}^{-1} \cdot \min ^{-1}(p<0.01)$ in the LAA and HAA intake groups, respectively.

Essential and nonessential amino acid concentrations are shown in Figure 4. Amino acid concentrations were increased for nearly all amino acids in the HAA versus LAA intake groups.

Table 2. Nutrient intake during the 24-hr period ending with the conclusion of the isotope study

\begin{tabular}{lcc}
\hline & Low amino acid intake group & High amino acid intake group \\
\hline Amino acids, $\mathrm{g} \cdot \mathrm{kg}^{-1} \cdot \mathrm{day}^{-1}$ & $0.85 \pm 0.08$ & $2.65 \pm 0.13 *$ \\
Glucose $\mathrm{mg} \cdot \mathrm{kg}^{-1} \cdot \mathrm{min}^{-1}$ & $6.4 \pm 0.7$ & $7.6 \pm 0.8$ \\
$\mathrm{Lipid}, \mathrm{g} \cdot \mathrm{kg}{ }^{-1} \cdot \mathrm{day}^{-1}$ & $1.00 \pm 0.09$ & $1.18 \pm 0.09$ \\
Non-protein caloric intake, $\mathrm{mJ} / \mathrm{kg} / \mathrm{d}(\mathrm{cal} / \mathrm{kg} / \mathrm{d})$ & $174 \pm 16(41.5 \pm 3.7)$ & $206 \pm 18(49.1 \pm 4.3)$ \\
\hline
\end{tabular}

Values expressed as mean \pm SEM.

* Significant difference between groups, $p<0.00001$. 


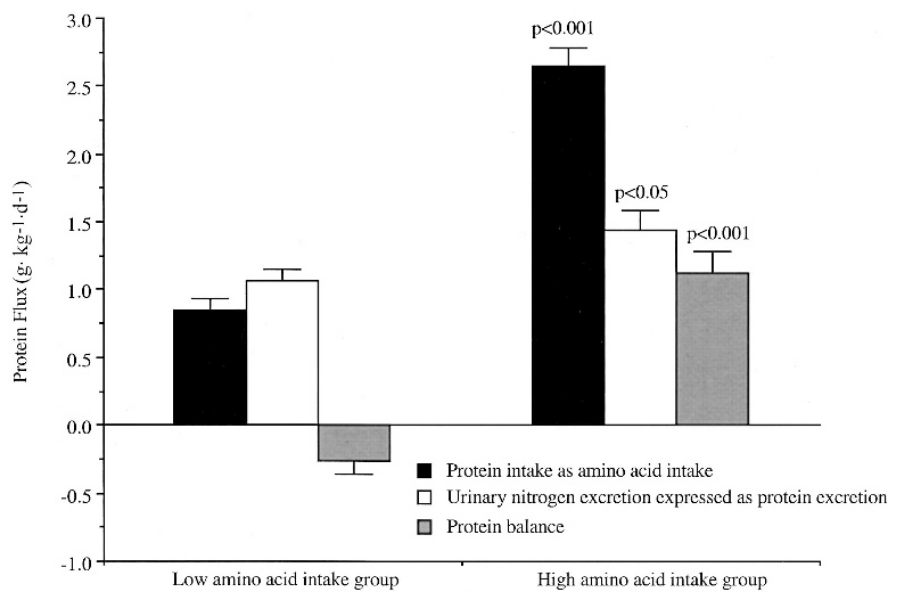

Figure 1. Amino acid intake (expressed as protein intake; solid bars), urinary nitrogen excretion (expressed as protein excretion; hatched bars), and resulting protein balance (shaded bars) at low $\left(1 \mathrm{~g} \cdot \mathrm{kg}^{-1} \cdot \mathrm{d}^{-1}\right)$ and high $\left(3 \mathrm{~g} \cdot \mathrm{kg}^{-1} \cdot \mathrm{d}^{-1}\right)$ amino acid intakes. Values expressed as mean and SEM.

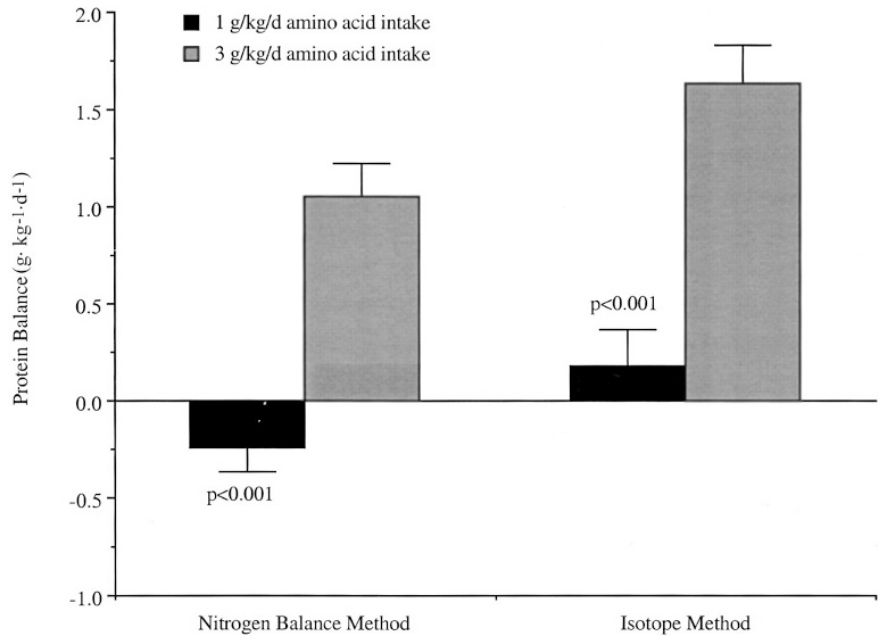

Figure 2. Comparison of protein balance results using two different methods. Solid and shaded bars indicate balance at intake of 1 and $3 \mathrm{~g} \cdot \mathrm{kg}^{-1} \cdot \mathrm{d}^{-1}$ amino acid intake, respectively. Values expressed as mean and SEM.

\section{DISCUSSION}

Preterm infants who receive only supplemental glucose lose $1 \%$ of protein stores each day (17). Several previous investigations have demonstrated the beneficial effect of early parenteral amino acids on decreasing protein loss in preterm infants. In general, it appears that $1.5-2.0 \mathrm{~g} \cdot \mathrm{kg}^{-1} \cdot \mathrm{d}^{-1}$ of parenteral amino acid administration is sufficient to avoid negative protein balance in all neonatal populations if concomitant catabolic conditions are not present (e.g. sepsis or dexamethasone administration), and this value may be as little as $1.0-1.5$ $\mathrm{g} \cdot \mathrm{kg}^{-1} \cdot \mathrm{d}^{-1}$ in ELBW infants (8-19). These studies during the past 20 y have gradually increased the amount of amino acid intake and shortened the time after birth before initiation of parenteral alimentation, but have not yet validated the efficacy and tolerance of intakes sufficient to prevent postnatal undernutrition. It has been estimated that attaining intrauterine rates of protein deposition may require as much as $3.85 \mathrm{~g} \cdot \mathrm{kg}^{-1} \cdot \mathrm{d}^{-1}$ of amino acid intake in the smallest ELBW infants $(31,32)$. This is the first randomized study in very preterm neonates immediately after birth to investigate a parenteral amino acid intake that approaches the fetal amino acid delivery rate at this gestation $(9,32)$.

In this study efficacy of increased amino acid intake was determined by protein balance (presumed protein accretion rate) as determined by nitrogen balance and leucine stable isotope methods. As we have seen previously in a similar population (19), there was a strong correlation between the two methods in determination of protein balance $\left(r^{2}=0.661, p<\right.$ 0.0001 ), although protein balance values tended to be higher by the isotope method (Fig. 2). Of the two methods, nitrogen balance may be less accurate in this age group because of the relatively short urine collection period and the frequent changes in urine output rate in these small infants.

Stable isotope methodology allows for measurement of the various components of protein metabolism. As seen in Table 3, very preterm infants have very high leucine rates of appearance from protein breakdown and nonoxidative leucine disposal (reflecting rates of protein breakdown and synthesis, respectively) when compared with the rate of leucine balance. These data further substantiate previous observations of significantly higher protein synthesis and breakdown rates in very low birth weight infants $(11,16,19,33,34)$.

Although a study of term, enterally fed newborns did not demonstrate an increase in leucine oxidation with feeding (35), leucine oxidation in preterm neonates has been shown to increase with increasing leucine intake (16). In the present study, leucine intake was highly correlated with leucine flux and oxidation rates (Fig. 3, Top). The amino acid intake in this study is higher than previously reported in neonatal studies, and it is likely, given the relatively low nonprotein energy intake (Table 2), that amino acids may have been used as an

Table 3. Leucine metabolism by stable isotope method

\begin{tabular}{lcc}
\hline & Low amino acid intake group & High amino acid intake group \\
\hline $\mathrm{Q}_{\text {leuc }},\left(\mu \mathrm{mol} \cdot \mathrm{kg}^{-1} \cdot \mathrm{h}^{-1}\right)$ & $164.3 \pm 7.7$ & $249.1 \pm 12.6^{*}$ \\
$\mathrm{Int}_{\text {leuc }}\left(\mu \mathrm{mol} \cdot \mathrm{kg}^{-1} \cdot \mathrm{h}^{-1}\right)$ & $36.7 \pm 4.0$ & $109.0 \pm 6.6^{*}$ \\
$\mathrm{Ox}_{\text {leuc }}\left(\mu \mathrm{mol} \cdot \mathrm{kg}^{-1} \cdot \mathrm{h}^{-1}\right)$ & $32.2 \pm 2.8$ & $68.8 \pm 5.4^{*}$ \\
$\mathrm{NOD}_{\text {leuc }}\left(\mu \mathrm{mol} \cdot \mathrm{kg}^{-1} \cdot \mathrm{h}^{-1}\right)$ & $132.1 \pm 7.7$ & $180.3 \pm 10.2^{* *}$ \\
$\mathrm{RP}_{\text {leuc }}\left(\mu \mathrm{mol} \cdot \mathrm{kg}^{-1} \cdot \mathrm{h}^{-1}\right)$ & $127.6 \pm 8.2$ & $140.2 \pm 14.8$ \\
$\mathrm{Bal}_{\text {leuc }}\left(\mu \mathrm{mol} \cdot \mathrm{kg}^{-1} \cdot \mathrm{h}^{-1}\right)$ & $4.5 \pm 4.2$ & $40.1 \pm 5.0^{*}$ \\
$\mathrm{Bal}_{\text {pro }}\left(\mathrm{g} \cdot \mathrm{kg}^{-1} \cdot \mathrm{d}^{-1}\right)$ & $0.18 \pm 0.17$ & $1.63 \pm 0.20^{*}$ \\
\hline
\end{tabular}

$\mathrm{Q}_{\text {leuc }}$ is the leucine flux rate, $\mathrm{Int}_{\text {leuc }}$ is leucine intake from the diet plus leucine from the isotope infusion, $\mathrm{Ox}_{\text {leuc }}$ is leucine oxidation rate, $\mathrm{NOD}_{\text {leuc }}$ is leucine non-oxidative disposal rate, $\mathrm{RP}_{\text {leuc }}$ is leucine released from protein breakdown, $\mathrm{Bal}_{\text {leuc }}$ is leucine balance, and $\mathrm{Bal}_{\text {pro }}$ is protein balance. Values expressed as mean \pm SEM. Significant difference between groups, ${ }^{*} p<0.0001,{ }^{*} p<0.005$. 

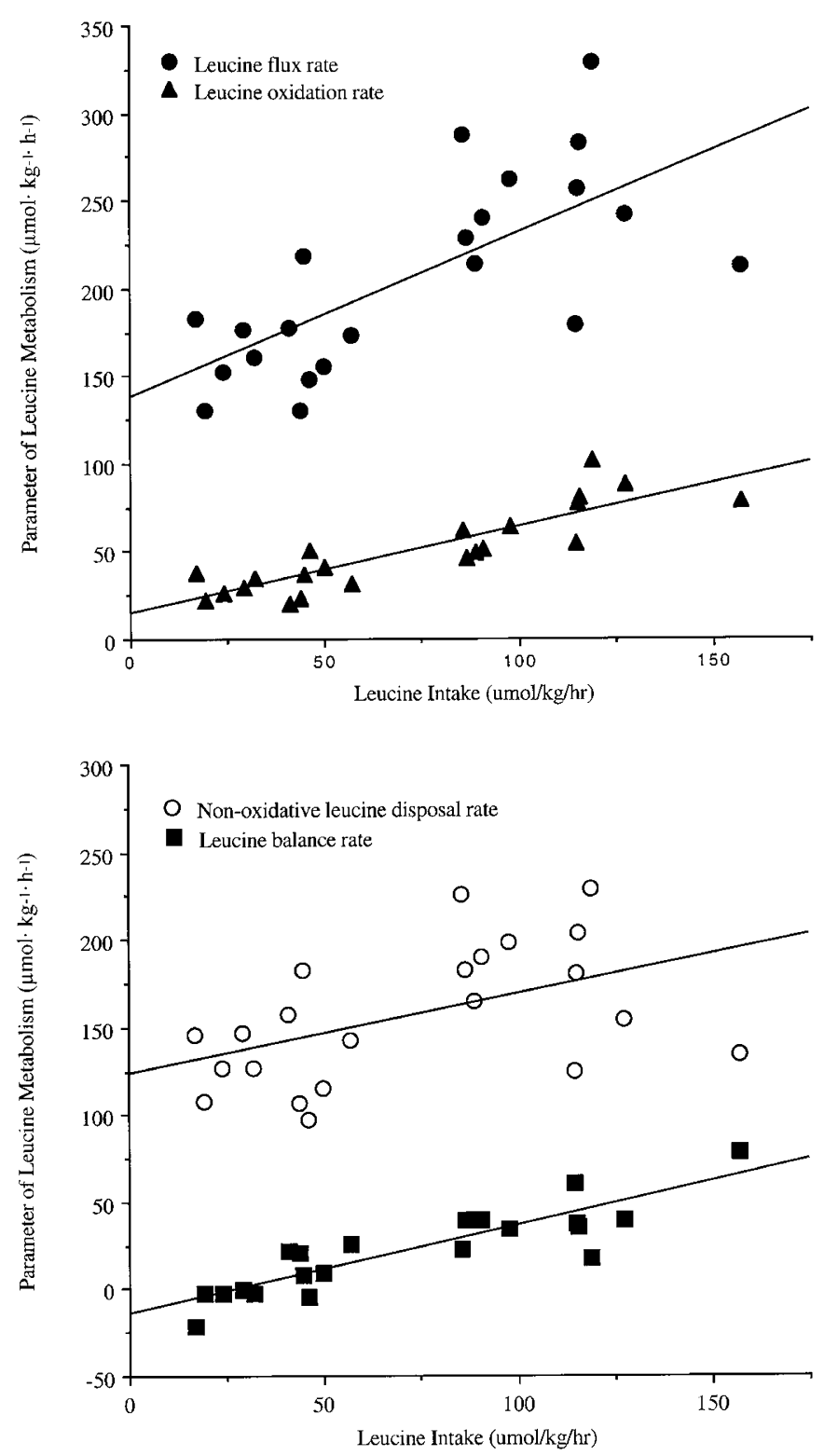

Figure 3. By regression analysis, there was significant correlation between leucine intake rate and the measured values (Top) of leucine flux rate $(-p<<$ $\left.0.0005, r^{2}=0.50\right)$ and leucine oxidation rate $\left(\mathbf{\Delta} ; p<0.0001, r^{2}=0.76\right)$, as well as the calculated values (Bottom) of nonoxidative leucine disposal rate $(0$; $\left.p<0.05, r^{2}=0.23\right)$ and leucine balance rate $\left(\boldsymbol{\square} ; p<0.0001, r^{2}=0.76\right)$.

energy source at the higher amino acid intakes. Optimal energy to amino acid intake ratios have not been determined for maximal protein accretion rates. We speculate that protein oxidation might be increased in those ELBW infants who are on the lowest energy intakes immediately after birth as a means to provide an additional energy source at a gestational age when there are minimal fat stores.

Animal studies indicate that the newborn is highly efficient at using amino acids for protein accretion (36), and that this efficiency is inversely related to postnatal age (37). The literature, however, has been somewhat conflicting regarding the mechanism by which amino acid intake promotes protein accretion in neonates. In adults, the majority of studies have suggested that protein accretion occurs with feeding by suppression of protein breakdown (38-41), although others have implicated increasing protein synthesis (42) or a combination of the two mechanisms (43). Studies in older children (44) and in preterm neonates $(16,45)$ suggest that the effect of amino acid intake on protein accretion occurs by increased protein synthesis rather than inhibition of protein breakdown. In a study comparing stable, parenterally fed term versus extremely preterm newborns, Denne et al. (45) demonstrated similar significant increases in protein synthesis with $\mathrm{PN}$, but there was significantly less suppression of protein breakdown in the preterm neonate. The present study has the advantage of studying very preterm neonates over a range of amino acid intakes; the rate of nonoxidative leucine disposal correlated with leucine intake, but leucine appearance from protein breakdown did not. Additionally, by the nitrogen balance method, amino acid intake clearly had a greater effect on protein balance than urinary nitrogen excretion (Fig. 1). Thus, both techniques suggest that the primary mechanism of protein accretion in parenterally fed very preterm infants in early life occurs by amino acid stimulation of protein synthesis rather than by suppression of protein breakdown.

Both amino acids and insulin are believed to regulate protein accretion. Their separate and interactive contributions to protein deposition, however, have not been well defined in the neonate. In early postnatal life, animal studies suggest that insulin secretion depends on glucose concentration as well as that of certain amino acids such as arginine and leucine (46). Denne et al. (45) demonstrated a significant increase in plasma insulin concentrations in both term and extremely preterm infants in response to PN consisting of glucose, lipid, and amino acids. However, in both groups of infants, baseline samples were done during fasting (term infants) or saline infusion (preterm infants), so the increase in insulin concentration could have been secondary to infusion of any of the three substrates or a combination thereof. The present study demonstrated an approximate doubling of insulin concentration in the HAA intake compared with the LAA intake study group. This is presumably because of the higher amino acid concentrations in the HAA intake group inasmuch as lipid and glucose intakes,

Table 4. Laboratory values

\begin{tabular}{lcc}
\hline & Low amino acid intake group & High amino acid intake group \\
\hline Blood urea nitrogen, $\mathrm{mmol} / \mathrm{L}(\mathrm{mg} / \mathrm{dL})$ & $7.2 \pm 0.9(20.2 \pm 2.8)$ & $9.5 \pm 1.1(26.5 \pm 3.0)$ \\
Creatinine, $\mu \mathrm{mol} / \mathrm{L}(\mathrm{mg} / \mathrm{dL})$ & $97 \pm 9(1.1 \pm 0.1)$ & $84 \pm 3(1.0 \pm 0.0)$ \\
Triglycerides, $\mathrm{mmol} / \mathrm{L}(\mathrm{mg} / \mathrm{dL})$ & $0.69 \pm 0.16(62 \pm 14)$ & $0.72 \pm 0.14(64 \pm 13)$ \\
Glucose, $\mathrm{mmol} / \mathrm{L}(\mathrm{mg} / \mathrm{dL})$ & $6.2 \pm 0.7(113 \pm 13)$ & $6.9 \pm 0.8(125 \pm 14)$ \\
Insulin, $\mathrm{pmol} / \mathrm{L}(\mu \mathrm{d} / \mathrm{mL})$ & $75 \pm 13(10.5 \pm 1.9)$ & $139 \pm 23(19.3 \pm 3.1)^{*}$ \\
\hline
\end{tabular}

Values expressed as mean \pm SEM.

* Significant difference between groups, $p<0.05$. 


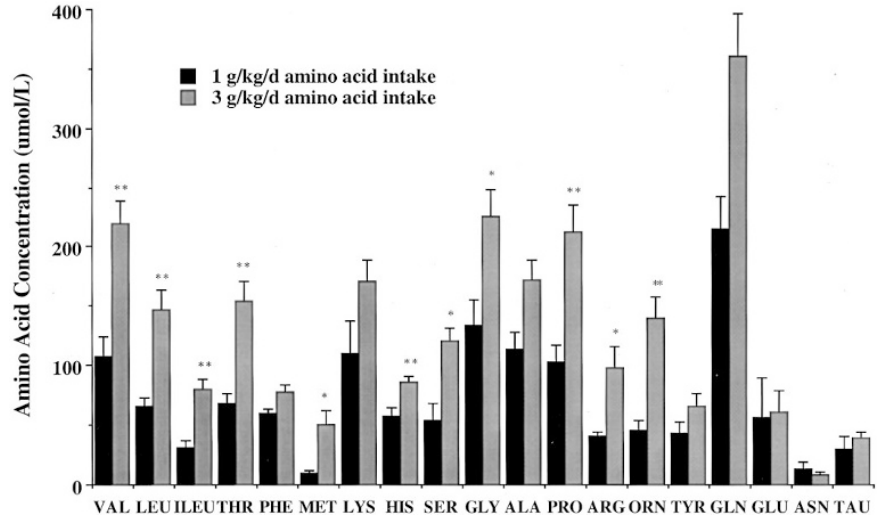

Figure 4. Plasma amino acid concentrations in LAA (solid bars) and HAA (hatched bars) groups. Values expressed as mean + SEM. Analysis of difference in balance for two intakes for each method determined by unpaired $t$ test. $* p<0.05, * * p<0.005$.

triglyceride and glucose concentrations, and glucose flux rates were similar in the two groups. Using a hyperinsulinemic, euaminoacidemic clamp in a neonatal piglet model, Wray-Cahen et al. (47) demonstrated that whole body amino acid disposal rate was related to the insulin concentration, and was more sensitive to insulin concentration in younger ( $7 \mathrm{~d}$ ) than older (26 d) animals. In the younger animals the threshold concentration for insulinstimulated amino acid disposal occurred at insulin concentrations $<8 \mu \mathrm{U} / \mathrm{mL}$, and the insulin concentration required to achieve the half-maximal utilization rate of exogenously administered amino acids was $18 \mu \mathrm{U} / \mathrm{mL}$. Both of these values are within the physiologic range of postfeeding insulin concentrations. Similarly, a hyperinsulinemic, euaminoacidemic clamp in fetal sheep demonstrated that physiologic increases in plasma insulin concentration increased net amino acid and nitrogen utilization rates in the ovine fetus independent of plasma glucose and amino acid concentrations, and the insulin concentration required to achieve the halfmaximal amino acid utilization rate ranged from 6 to $16 \mu \mathrm{U} / \mathrm{mL}$ for the essential amino acids (48). Additionally, it was estimated that two thirds of the increased leucine utilization rate was insulinspecific and one third was attributable to the increase in plasma leucine concentration. These animal data suggest that the higher insulin concentrations seen in the present study in the HAA versus LAA intake group may have been sufficient to play a significant role in the greater protein deposition seen in the HAA intake group.

In many institutions the introduction of amino acids in the first days of life in the preterm infant has been limited because of concerns regarding the inability of the immature infant to metabolize specific amino acids, potentially producing hyperammonemia, azotemia, and metabolic acidosis. Recent studies of early i.v. protein administration have not demonstrated abnormalities in any of these laboratory tests $(14-17,19,34)$. However, it is not known whether these are the appropriate markers for protein toxicity in the population of extremely preterm neonates. Metabolic acidosis is common in the ELBW population in the first days of life and may be secondary to a variety of causes; defining the specific contribution of amino acids to acidosis in such infants in the clinical setting may be impossible.

Clearly failure to fully metabolize amino acid substrate into protein synthesis can result in elevated blood urea levels. Furthermore, if, as is seen in the fetus, amino acids can be a significant energy source beyond the requirements for protein accretion, an elevated urea concentration in the ELBW infant may reflect an acceptable generation of an acceptable metabolic byproduct and not protein intolerance. However, in this study there was no correlation between amino acid intake and BUN concentration.

Under certain conditions, certain amino acids can be increased to potentially toxic levels. Essential and nonessential amino acid concentrations are shown in Figure 4. Amino acid concentrations were increased for nearly all amino acids in the HAA versus LAA intake groups, but even the HAA groups had concentrations comparable to those reported in studies of parenterally and enterally fed preterm neonates $(16,34,49,50)$. However, these may not be the appropriate comparison infants for very preterm infants with the goal of achieving fetal in utero protein accretion rates. For this reason, we compared neonatal amino acid concentrations in the HAA group with those of second and third trimester human fetuses in which cordocentesis was performed (51). Results are
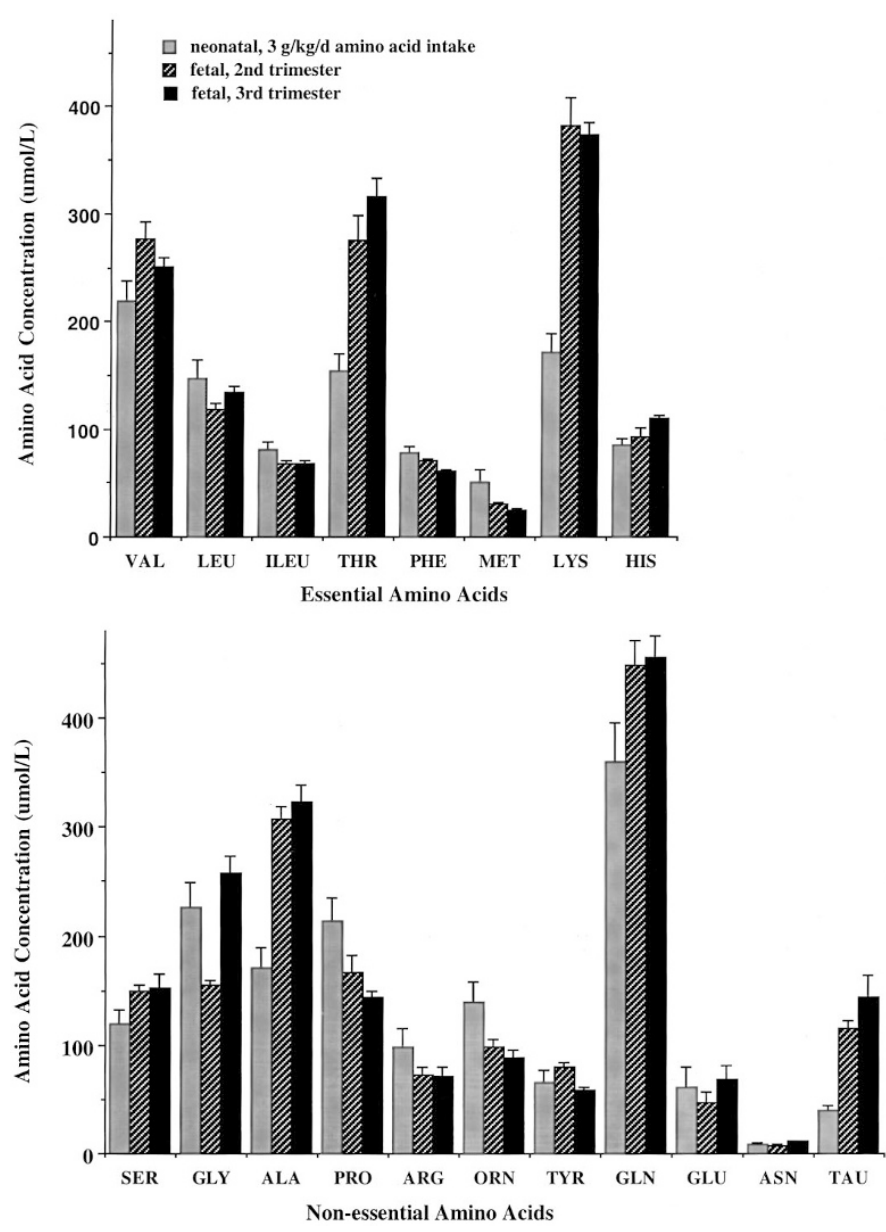

Figure 5. Comparison of essential (Top) and nonessential (Bottom) plasma amino acid concentrations in neonates receiving $3 \mathrm{~g} \cdot \mathrm{kg}^{-1} \cdot \mathrm{d}^{-1}$ parenteral amino acid intake with human fetal amino acids during the second and third trimesters of pregnancy [adapted from Cetin et al. (51)]. 
shown in Figure 5. In general, amino acid concentrations for both essential and nonessential amino acids were equal to or less than those seen in the fetus. Whether or not the lower concentrations of threonine and lysine in the HAA infants limited protein accretion relative to those in the growing human fetus remains to be determined.

\section{CONCLUSIONS}

This study demonstrates the efficacy of $3 \mathrm{~g} \cdot \mathrm{kg}^{-1} \cdot \mathrm{d}^{-1}$ versus $1 \mathrm{~g} \cdot \mathrm{kg}^{-1} \cdot \mathrm{d}^{-1}$ parenteral amino acid intake in improving protein accretion in very preterm neonates in the immediate postnatal period, and is the highest amino acid intake rate to be studied prospectively in this population in early life. This study and other investigations of early amino acid intakes in very preterm newborns have not suggested undue intolerance, although reliable and sensitive markers of amino acid toxicity that are readily available clinically have not been identified. Administering more aggressive amino acid intakes such as were used in this study can potentially avoid the early postnatal malnutrition commonly seen with current nutritional strategies. In addition, this study sets the stage for larger clinical trials on the effect of early, higher amino acid intake on duration of hospitalization, short- and long-term postnatal growth, and neurodevelopmental outcome.

\section{REFERENCES}

1. American Academy of Pediatrics, Committee on Nutrition 1998 Nutritional needs of preterm infants. In: Kleinman R (ed) Pediatric Nutrition Handbook. American Academy of Pediatrics, Elk Grove Village, IL, pp 55-87

2. Ziegler E 1991 Malnutrition in the premature infant. Acta Paediatr Scand Suppl 374:58-66

3. Lucas A 1995 Nutrition, growth and development of postdischarge, preterm infants. In: Hay Jr WW, Lucas A (eds) Posthospital Nutrition in the Preterm Infant. Ross Laboratories, Columbus, $\mathrm{OH}, \mathrm{pp}$ 81-89

4. Ehrenkranz R, Younes N, Lemons J, Fanaroff AA, Donovan EF, Wright LL, Katsikiotis V, Tyson JE, Oh W, Shankaran S, Bauer CR, Korones SB, Stoll BJ, Stevenson DK, Papile LA 1999 Longitudinal growth of hospitalized very low birthweight infants. Pediatrics 104:280-289

5. Micheli JL, Schutz Y 1993 Protein. In: Tsang RC, Lucas A, Uauy R, Zlotkin S (eds) Nutritional Needs of the Preterm Infant, Scientific Basis and Practical Guidelines. Caduceus Medical Publishers, Inc, Pawling, NY, pp 29-46

6. Hay Jr WW 1991 Nutritional requirements of the extremely-low-birth-weight infant In: Hay Jr WW (ed) Neonatal Nutrition and Metabolism. Mosby-Year Book, St. Louis, pp 361-391

7. Lucas A, Morley R, Cole TJ 1998 Randomised trial of early diet in preterm babies and later intelligence quotient. BMJ 317:1481-1487

8. Rubecz I, Mestyan J, Varga P, Klujber L 1981 Energy metabolism, substrate utilization, and nitrogen balance in parenterally fed postoperative neonates and infants. J Pediatr 98:42-46

9. Zlotkin SH, Bryan MH, Anderson GH 1981 Intravenous nitrogen and energy intakes required to duplicate in utero nitrogen accretion in prematurely born human infants. J Pediatr 99:115-120

10. Duffy B, Gunn J, Collinge J, Pencharz P 1981 The effect of varying protein quality and energy intake on the nitrogen metabolism of parenterally fed very low birthweight $(<1600 \mathrm{~g})$ infants. Pediatr Res 15:1040-1044

11. van Toledo-Eppinga L, Kalhan SC, Kulik W, Jakobs C, LaFeber HN 1996 Relative kinetics of phenylalanine and leucine in low birth weight infants during nutrient administration. Pediatr Res 40:41-46

12. Anderson TL, Muttart CR, Bieber MA, Nicholson JF, Heird WC 1979 A controlled trial of glucose versus glucose and amino acids in premature infants. J Pediatr 94:947-951

13. Yu VYH, James B, Hendry P, MacMahon RA 1979 Total parenteral nutrition in very low birthweight infants: a controlled trial. Arch Dis Child 54:653-661

14. Saini J, MacMahon P, Morgan JB, Kovar IZ 1989 Early parenteral feeding of amino acids. Arch Dis Child 64:1362-1366

15. van Lingen RA, van Goudoever JB, Luijendijk IH, Wattimena JL, Sauer PJ 1992 Effects of early amino acid administration during total parenteral nutrition on protein metabolism in pre-term infants. Clin Sci 82:199-203

16. Rivera Jr A, Bell EF, Bier DM 1993 Effect of intravenous amino acids on protein metabolism of preterm infants during the first three days of life. Pediatr Res $33: 106-111$
17. Kashyap S, Heird WC 1993 Protein requirements of low birthweight, very low birthweight, and small for gestational age infants. In: Raiha NCR (ed) Protein Metabolism During Infancy. Raven Press, New York, pp 133-151

18. van Goudoever JB, Sulkers EJ, Halliday D, Degenhart HJ, Carnielli VP, Wattimena JL 1995 Whole body protein turnover in preterm appropriate for gestational age and small for gestational age infants: comparison of $\left[{ }^{15} \mathrm{~N}\right]$ glycine and $\left[1-{ }^{13} \mathrm{C}\right]$ leucine administered simultaneously. Pediatr Res 37:381-388

19. Thureen PJ, Anderson AH, Baron KA, Melara DL, Hay Jr WW, Fennessey PV 1998 Protein balance in the first week of life in ventilated neonates receiving parenteral nutrition. Am J Clin Nutr 68:1228-1136

20. Thureen PJ, Phillips RE, DeMarie MP, Hoffenberg A, Bronstein MN, Spedale SB, Hay Jr WW 1997 Technical and methodologic considerations for performance of indirect calorimetry in ventilated and nonventilated preterm infants. Crit Care Med 25:171-179

21. Richardson DK, Gray JE, McCormick MC, Workman K, Goldmann DA 1993 Score for neonatal acute physiology: a physiologic severity index for neonatal intensive care. Pediatrics 91:617-623

22. Gray JE, Richardson DK, McCormick MC, Workman-Daniels K, Goldmann DA 1992 Neonatal therapeutic intervention scoring system: a therapy-based severity-ofillness index. Pediatrics 90:561-567

23. Loy GL, Quick AN, Teng CC, Hay Jr WW, Fennessey PV 1990 Versatile stable isotope technique for the measurement of amino acids and keto acids: comparison with radioactive isotopes and its use in measuring in vivo disposal rates. Anal Biochem 185:1-9

24. Denne SC, Kalhan SC 1986 Glucose carbon recycling and oxidation in human newborns. Am J Physiol 251:E71-E77

25. Pineault M, Maag U, Chessex P 1990 Reliability of the twenty-four-hour nitrogen balance in parenterally fed newborn infants. J Parenter Enter Nutr 14:53-55

26. Lopez AM, Wolfsdorf J, Raszynski A, Contijoch-Serrano V 1986 Estimation of nitrogen balance based on a 6-hour urine collection in infants. J Parenter Enter Nutr 10:517-518

27. Matthews DE, Motil KJ, Rohrbaugh DK, Burke JF, Young VR, Bier DM 1980 Measurement of leucine metabolism in man from a primed continuous infusion of L- $\left[1-{ }^{13} \mathrm{C}\right]$ leucine. Am J Physiol 238:E473-E479

28. Van Aerde JEE, Sauer PJJ, Pencharz PB, Canagarayar U, Beesley J, Smith JM, Swyer PR 1985 The effect of energy intake and expenditure on the recovery of ${ }^{13} \mathrm{CO}_{2}$ in the neonate during 4-hour primed constant infusion of $\mathrm{Na}^{13} \mathrm{CO}_{3}$. Pediatr Res 19:806-810

29. Allsop JR, Wolfe RR, Burke JF 1978 Tracer priming of the bicarbonate pool. J Appl Physiol 45:137-139

30. Waterlow J, Garlick P, Millward D 1978 Total protein turnover from measurements on plasma and on the whole body. In: Waterlow J, Garlick P, Millward D (eds) Protein Turnover in Mammalian Tissues and in the Whole Body. Elsevier/NorthHolland Biomedical Press, Amsterdam, pp 301-325

31. Ziegler EE 1986 Protein requirements of preterm infants. In: Fomon SJ, Heird WC (eds) Energy and Protein Needs During Infancy. Academic Press, New York, pp $69-85$

32. Ziegler EE 1994 Protein in premature feeding. Nutrition 10:69-71

33. Battista MA, Price PT, Kalhan SC 1996 Effect of parenteral amino acids on leucine and urea kinetics in preterm infants. J Pediatr 128:130-134

34. van Goudoever JB, Colen T, Wattimena JLD, Huijmans JGM, Carnielli VP, Sauer PJJ 1995 Immediate commencement of amino acid supplementation in preterm infants: effect on serum amino acid concentrations and protein kinetics on the first day of life. J Pediatr 127:458-465

35. Denne SC, Rossi EM, Kalhan SC 1991 Leucine kinetics during feeding in normal newborns. Pediatr Res 30:23-27

36. Fiorotto M, Burrin D, Perez M, Peeds P 1991 Intake and use of milk nutrients by rat pups suckled in small, medium, or large litters. Am J Physiol 260:R1104-R1113

37. Davis T, Burrin D, Fiorotto M, Nguyen H 1996 Protein synthesis in skeletal muscle and jejunum is more responsive to feeding in 7- than in 26-day old pigs. Am J Physiol 270:E802-E809

38. Motil KJ, Matthews DE, Bier DM, Burke JF, Munro HN, Young VR 1981 Wholebody leucine and lysine metabolism: response to dietary protein intake in young men Am J Physiol 240:E712-E721

39. Melville S, McNurlan MA, McHardy KC, Broom J, Milne E, Calder AG, Garlick PJ 1989 The role of degradation in the acute control of protein balance in adult man: failure of feeding to stimulate protein synthesis as assessed by $\mathrm{L}-\left[1-{ }^{13} \mathrm{C}\right]$ leucine infusion. Metabolism 38:248-255

40. Castellino P, Luzi L, Simonson D, Haymond M, DeFronzo R 1987 Effect of insulin and plasma amino acid concentrations on leucine metabolism in man. J Clin Invest 80:1784-1793

41. Flakoll P, Kulaylat M, Frexes-Steed M, Hourani H, Brown LL, Hill JO, Abumrad NN 1989 Amino acids augment insulin's suppression of whole body proteolysis. Am J Physiol 257:E839-E847

42. Rennie MJ, Edwards RHT, Halliday D, Matthews DE, Wolman SL, Millward DJ 1982 Muscle protein synthesis measured by stable isotope techniques in man: the effect of feeding and fasting. Clin Sci 63:519-523

43. Hoffer LJ, Yang RD, Matthews DE, Bistrian BR, Bier DM, Young VR 1985 Effects of meal consumption on whole body leucine and alanine kinetics in young adult men. Br J Nutr 53:31-38

44. Goulet O, DePotter S, Salas J, Robert JJ, Rongier M, Hariz MB, Koziet J, Desjeux JF, Ricour C, Darmaun D 1993 Leucine metabolism at graded amino acid intakes in children receiving parenteral nutrition. Am J Physiol 265:E540-E546

45. Denne SC, Karn CA, Ahlrichs JA, Dorotheo AR, Wang J, Liechty EA 1996 Proteolysis and phenylalanine hydroxylation in response to parenteral nutrition in extremely premature and normal newborns. J Clin Invest 97:746-754 
46. Dauncey MJ, Rudd BT, White DA, Shakespear RA 1993 Regulation of insulin-like growth factor binding proteins in young growing animals by alteration of energy status. Growth Regul 3:198-207

47. Wray-Cahen D, Beckett PR, Nguyen HV, Davis TA 1997 Insulin-stimulated amino acid utilization during glucose and amino acid clamps decreases with development. Am J Physiol 273:E305-E314

48. Thureen PJ, Scheer B, Anderson SM, Tooze JA, Young DA, Hay Jr WW 2000 Effect of hyperinsulinemia on amino acid utilization in the ovine fetus. Am J Physio 279:E1294-E1302
49. Helms RA, Christensen ML, Mauer EC, Storm MC 1987 Comparison of a pediatric versus standard amino acid formulation in preterm neonates requiring parenteral nutrition. J Pediatr 110:466-470

50. Heird WC, Hay Jr WW, Helms RA, Storm MC, Kashyap S, Dell RB 1988 Pediatric parenteral amino acid mixture in low birth weight infants. Pediatrics $81: 41-50$

51. Cetin I, Corbetta C, Sereni LP, Marconi AM, Bozzetti P, Pardi G, Battaglia FC 1990 Umbilical amino acid concentrations in normal and growth-retarded fetuses sampled in utero by cordocentesis. Am J Obstet Gynecol 162:253-261 